\title{
Studies on Water Sorption Behaviour of Laminated Bamboo Polymer Composite
}

\author{
Yuniar Ratna Pratiwi*', Indah Widiastuti, and Budi Harjanto \\ Department of Mechanical Engineering Education, Universitas Sebelas Maret, J1. Ir Sutami No.36 A \\ ,Surakarta, Central Java, 57126, Indonesia
}

\begin{abstract}
The aim of this article is to evaluate water absorption in bamboo fiber composites. Bamboo is hydrophilic, means that it easily absorbs water. In this study the bamboo fiber-based composites were developed using hand lay up method, with epoxy resin as the matrix constituent. Water absorption characteristics of specimens of bamboo composite and epoxy were determined from water immersion tests at several temperatures. Gravimetric analysis was performed to determine the moisure absorbed as a function of time at two different temperatures: $25^{\circ} \mathrm{C}$ and $50{ }^{\circ} \mathrm{C}$. The diffusivity of water in an epoxy bamboo composite was determined after reaching saturation point. During room temperature soaking, epoxy specimen showed the characteristic of Fickian behavior. Similar immersion tests on bamboo-epoxy composites followed nonfickian behavior. Changes in the mechanical properties of material due to water absorption were evaluated from tensile testing on materials with varied water content. It was found that the water absorption in all samples reduced the tensile properties. The degradation of tensile properties was greater with an increasing temperature of immersion. The results of this study emphasize the importance of considering deterioration of mechanical properties in the bamboo epoxy composites during their application in water and possibly in humid environment.
\end{abstract}

Key words: Bamboo composite, degradation, mechanical properties, water diffusion.

\section{Introduction}

Interest in natural fiber composite materials is growing for outdoor application such as wind turbine blades and some components of aircraft. Natural fiber composites are also suitable for tools that must be strong and light. Not only are natural fiber composites environmentally friendly, and light weight, but they are also economical to fabricate, they have a relatively high specific strength and stiffness, good fatigue strength and a low density [1-4].

Bamboo polymer composites are the latest development in natural fiber composites, utilizing the advantanges of bamboo in many form, such as fibers, strips, or webbing and combined it with thermoplastic polymers (such as: PVC, polypropylene, polyethylene) or

\footnotetext{
* Corresponding author: yuniarratnapratiwi@gmail.com
} 
thermosetting polymers (such as: polyester,vinylester,epoxy). Bamboo is herbaceous plant with hollowed and flavored stems. It grows easily in Southeast Asia, South America and some countries in Africa. Bamboo require $3 \mathrm{yr}$ to $4 \mathrm{yr}$ grow to reach the maturity point. Tensile strengh of bamboo fibers at maturity point can be comparable to mild steel [5-7], but with a much lower density and a high specific modulus of elasticity. Furthermore, it is more readily available and abundant than most other natural fibers [8].

Bamboo fiber consists of cellulose, hemi-celluloses, lignin, pectin, and waxy subtances that make it more sensitive to humidity. Chemical elements in bamboo called cellulose had hydrophilic characteristic that makes bamboo easily absorp water. Humid environments in long term will cause bamboo polymeric composite swelling. The consequence of swelling could be an increase in outdoor application of bamboo polymer composites. Swelling in the composite occurs because the hydrophilic $\mathrm{OH}$ groups react with water in humid environment causing the composite readily absorb moisure which will generally degrade of mechanical properties of the composites [9-11].

The characteristic of water absorption in bio-composite has been examined by some researchers. Composite with laminate fiber orientation gives lower water absorption, but also higher result in tensile and flexural strengh compared with composite with strip fiber. Abdul Some' studies reported that water absorption in composites increacese with long term immersion time and higher temperatures of immersion [12]. Immersion over particular period showed that water absorption of composite increases and the mechanism follows the Fickian diffusion process. However, another researcher concluded that the mechanism of water absoption of fiber composite deviated from Fickian diffusion process [13].

Mechanical properties of bamboo polymer composite might be affected by water absorption from a humid environment. One study reported that increasing the amount of water content within the composite material can cause the deterioration of the mechanical properties of natural fiber composite [14, 15]. Dhakal et al. [16] also reported that the increasing of water absorption in bamboo composites causes the mechanical properties to drop dramatically.

This study presents the characteristic of water absorption in bamboo polymer composites and epoxy resins. Gravimetric analysis was performed to determine changes of moisure content during immersion at two different temperatures: room temperature $\left(25^{\circ} \mathrm{C}\right)$, and $50{ }^{\circ} \mathrm{C}$. The diffusivity for water in epoxy and the diffusion coefficient value for a bamboo composite was determined after reaching saturation point. During room temperature water immersion, epoxy specimen showed the characteristic of Fickian behavior. Meanwhile, the immersion of bamboo fiber composites was found to have nonFickian behavior. Changes in the mechanical properties of specimens (epoxy and bamboo composites) due to water absorption were evaluated from tensile testing on materials with varied water content. It was found that the water absorption in all sample affected the tensile properties. Degradation of tensile properties was observed with increasing the temperature of immersion and associated quantities of water absorbed.

\section{Materials and methods}

\subsection{Materials}

The matrix material used in this study was a epoxy resin diglycidyl ether of bisphenol A (DEGBA) and with hardener cycloaliphatic amine EPH 555. This resin could be applied in various type of composite fabrication. Epoxy resin needs some sort of liquid diluent to reduce the viscosity [17]. 
The material for the reinforcement was bamboo wulung that a local indigenous grow in Indonesia. The from of bamboo is woven that obtained from local traditional craftmenThe woven bamboo mats were cut according standard test of ASTM3039 [ $(256 \times 25.6 \times 4)$ $\mathrm{mm})$ ] [18]. In every strip of bamboo has a thickness of $0.5 \mathrm{~mm}$ with a width of $5 \mathrm{~mm}$ to $8 \mathrm{~mm}$.
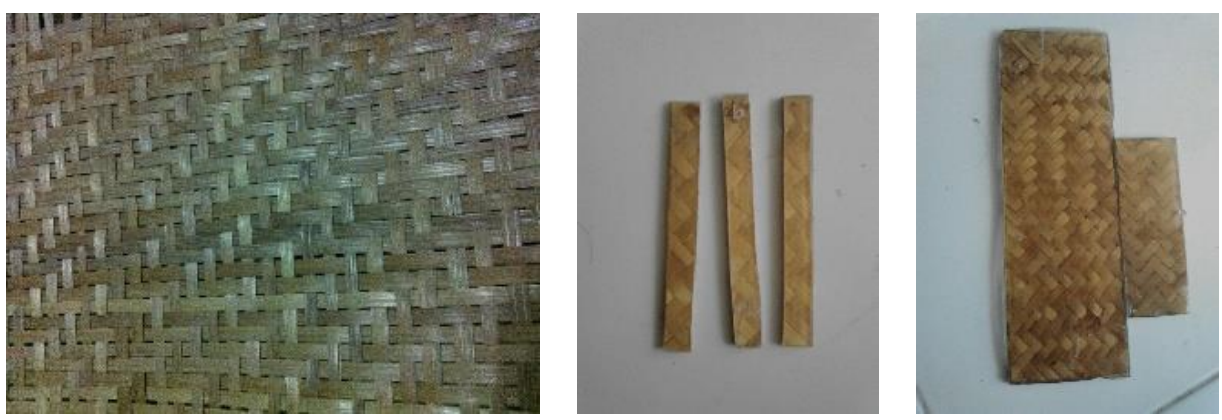

Fig. 1. Woven-bamboo/epoxy composite [19].

Aquades was used to the immersion experiment of bamboo composite. The aquades provided by BRATACHEM which constitue distillation of water. In varying levels of fluid concentration, different immersion temperature were used to accelerate the level of water absorption.

\subsection{Composite fabrication}

Hand lay up was chosen to make bamboo polymer composite, this method was performed by manually applying the epoxy resin and woven bamboo in the mold, respectively. The laminates of bamboo composite consited of three epoxy layers and two bamboo mat layers. Tha uniform ratio between epoxy resin and reinforced must be maintance in $25 \%$ reinforced material and $75 \%$ matrix materials.

Table 1. Designation of composite specimens.

\begin{tabular}{|c|l|}
\hline Designation & \multicolumn{1}{c|}{ Treatment of Composite specimens } \\
\hline BC-WI & Bamboo Composite Without Treatment \\
\hline FE-WI & Epoxy Specimens Without Treatment \\
\hline BC-RT & Bamboo Composite with Room Temperature Immersion \\
\hline FE-RT & Epoxy Specimen with Room Temperature Immersion \\
\hline BC-50 & Bamboo Composite with $50^{\circ} \mathrm{C}$ Immersion \\
\hline FE-50 & Epoxy Specimen with $50^{\circ} \mathrm{C}$ Immersion \\
\hline
\end{tabular}

\subsection{Immersion method}

The immersion method was performed by varying the temperature immersion into two different conditions: (i) room temperature $\left( \pm 25{ }^{\circ} \mathrm{C}\right)$, and (ii) $50{ }^{\circ} \mathrm{C}$. Gravimetric 
measurement was performed to determine changes of moisure content during immersion process. The bamboo composite spesimens were removed periodically for weight measurement until saturation occurs.

The weight gain of specimens was measured using the following relationship:

$$
\operatorname{Mt}(\%)=\frac{\mathrm{m}_{\mathrm{t}}-m_{0}}{m_{0}} \times 100
$$

Where $m_{0}$ and $m_{t}$ is the weight of dry specimens and wet specimen before and after immersion.

\subsection{Testing on mechanical properties}

Mechanical test are performed to evaluating degradation with different amount of water absorption in varying temperature of immersion. Tensile testing was performed under an international standard, ASTM D3039. This standard is for tensile properties of polymer composites. The samples tested were rectangular samples made using hand lay up method and glass mould. Specimens were cuts according to ASTM D3039 with $256 \mathrm{~mm}$ length, $25.6 \mathrm{~mm}$ to $25.9 \mathrm{~mm}$ width and $4 \mathrm{~mm}$ thickness. The samples were tested to failure under tension by using Hounsfield Universal Testing Machine.

The following equation is applied to calculated tensile strength generated on each samples in varying temperature of immersion.

$$
\sigma=\frac{F}{A_{0}}
$$

where $\mathrm{F}$ is load of samples and $\mathrm{A}_{0}$ is cross-sectional area of specimens. The tensile extension $(\varepsilon)$ of samples can be calculated with the following equation:

$$
\varepsilon=\frac{\Delta l}{l}
$$

Where $\Delta l$ represent the length of samples, and $l$ is the initial length of samples. Then, modulus elastisity of samples can be formulated by dividing the load of samples with the tensile extention of the samples :

$$
E=\frac{\sigma}{\varepsilon}
$$

\section{Results and discussion}

\subsection{Result on diffusions experimental}

Immersion was applied in two type of samples, epoxy samples and bamboo polymer composite samples, with varying temperature in room temperature and $50{ }^{\circ} \mathrm{C}$. The immersion of epoxy samples was observed to prove that this kind of polymer also absorp water event though in very small quantities.

Figure 2 shows the water absorption for all samples in room temperature immersion and $50{ }^{\circ} \mathrm{C}$ immersion as a function of immersion in hours. Each data point represents the average of five specimens. This shows that water content in every samples increase periodically. 


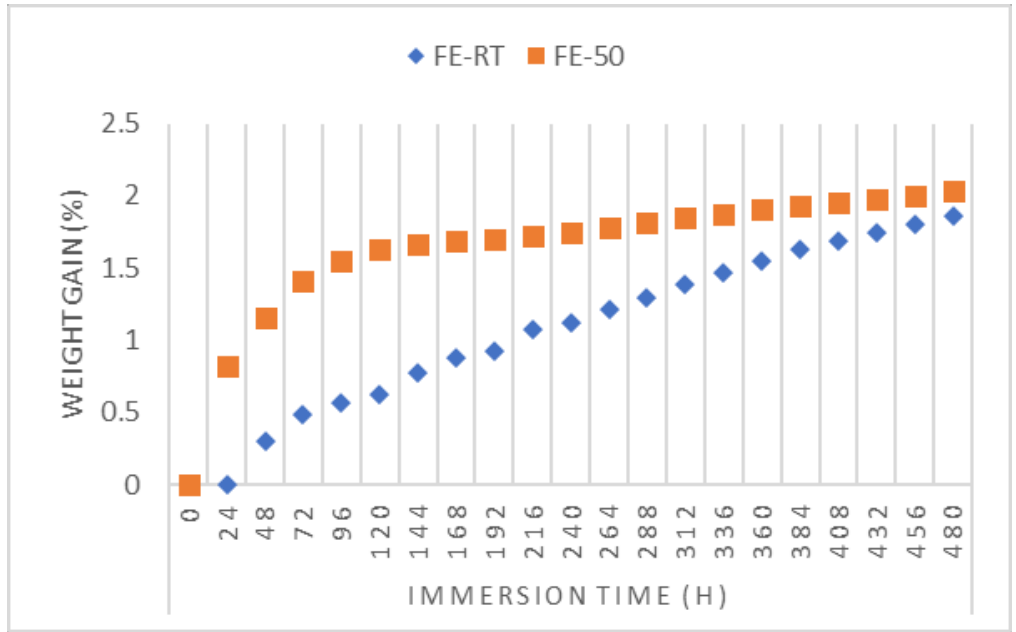

(a)

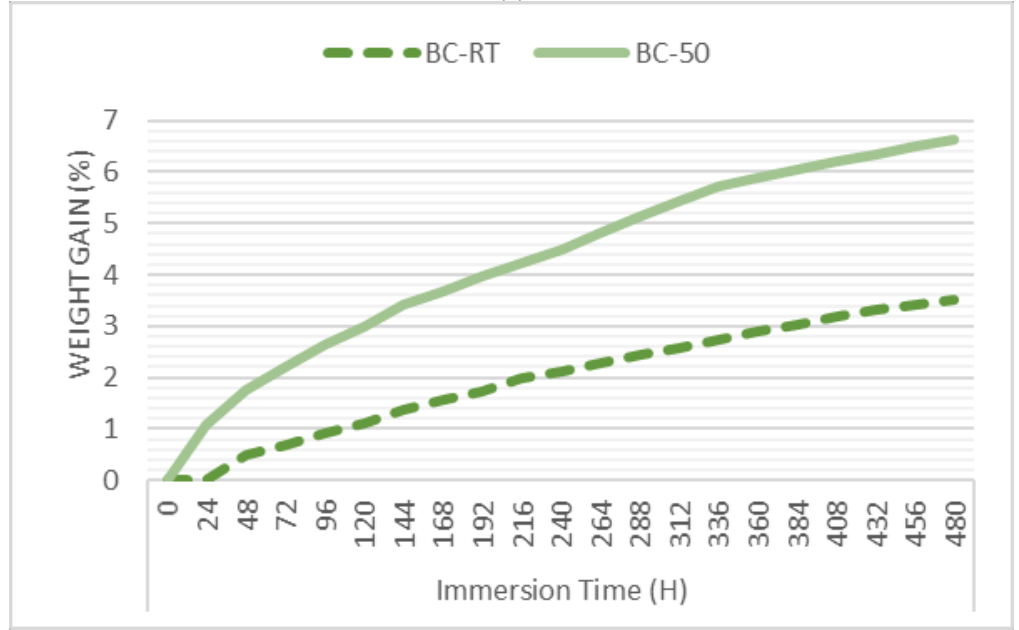

(b)

Fig. 2. Water uptake in (a) epoxy specimens and (b) bamboo composite specimens.

Epoxy specimen with room temperature and $50{ }^{\circ} \mathrm{C}$ immersion showed there was a small difference in level of water absorption (Figure 2a). After $24 \mathrm{~h}$ of room temperature immersion, the water content in specimen increases slowly and periodically, then reach $1.8 \%$ water content at $456 \mathrm{~h}$. Meanwhile, fot the same specimen in $50{ }^{\circ} \mathrm{C}$, significant increase of water content was observed 48 hours. The water content of epoxy specimen in $50{ }^{\circ} \mathrm{C}$ immersion temperature increased linearly and reach $1.8 \%$ of saturated weight gain with the room temperature immersion at $168 \mathrm{~h}$ following the Fickian Law of diffusion. It could be conclude that there was an impact of temperature immersion in the water content of specimen. The water content of epoxy specimen increases with increase the temperature of immersion [12, 20-22].

In contrast with that, Figure $2 b$ shows the significant increase of water content inside the bamboo composite. Epoxy specimens absorb water less water than the composite [23]. At $480 \mathrm{~h}$ immersion, bamboo composite with room temperature immersion was reached $3.5 \%$ of water content. In the other hand, at $480 \mathrm{~h}$, bamboo composite with bamboo polymer composite $50{ }^{\circ} \mathrm{C}$ immersion was reached $6.7 \%$ of water content. The changes of water absorption affected by bamboo filler in the composite. Cellulose of bamboo fibers 
had hydrophilic makes bamboo composite easily absorb water. It can be said that the bamboo fiber impact the water absorption of bamboo composites. In addition, increasing the temperature of immersion could be increase the water absorption of bamboo polymer composite larger [24, 25].

\subsection{Tensile properties}

Figure 3 represent the tensile strength and modulus elastisity of all specimen with immersion and without immersion. The tensile properties evaluated were tensile strength, modulus, and strain. It can be seen that the tensile strength and modolus elastisity of epoxy specimen without immersion is smaller than bamboo composite without immersion. Specimen of epoxy had tensile strength at 3.2 MPa, and modulus elastisity at 4. Meanwhile, bamboo composite without immersion had a bigger tensile strength with $45.5 \mathrm{MPa}$ at tensile strength and 1752 at modulus elastisity. It is found that the bamboo fiber impact the tensile strength and modulus elastisity of composites. Bamboo fiber in composite give the better tensile stength and modulus elastisity of composite.

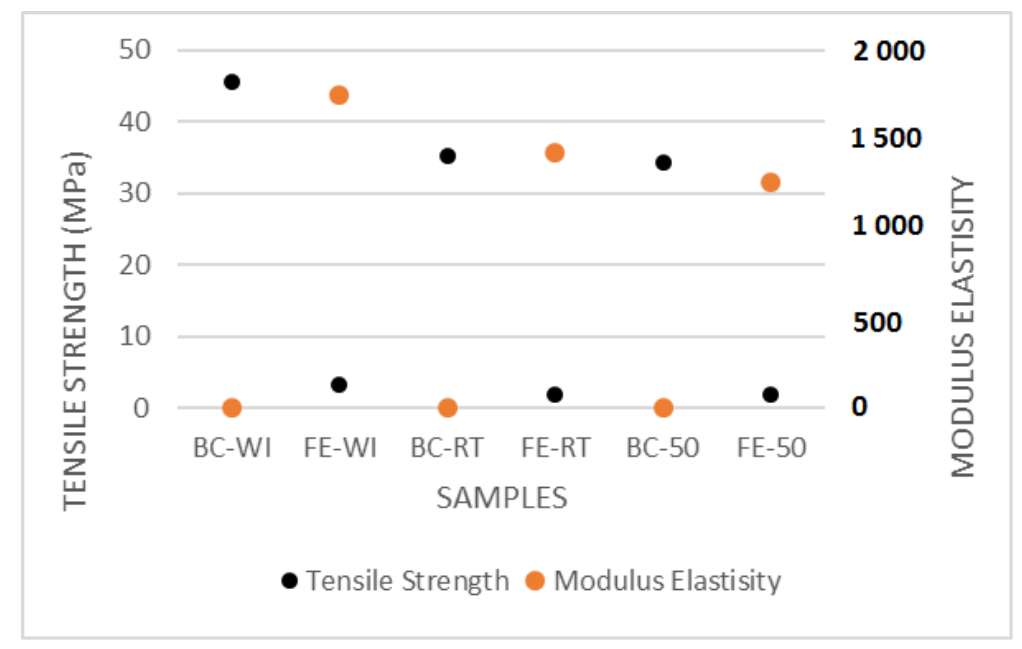

Fig. 3. Tensile properties of epoxy and bamboo composite specimens.

Immersion treatment affects the tensile strength and modulus elastisity of epoxy and bamboo composite specimen. It can be seen that the tensile strength and modulus elastisity of bamboo composite decrease progressively as a function of increasing the temperature of immersion. The specimen without treatment has tensile strength of $45.5 \mathrm{MPa}$ for bamboo composite, and 3.2 for epoxy specimen. In addition, modulus elastisity for that is 1752 for bamboo composite and 4 for epoxy specimen. Tensile strength modulus was observed after water immersion with varied temperature, there are decreases with increasing the water absorption, from 35.2 $\mathrm{MPa}$ to $34.4 \mathrm{MPa}$ for tensile strength of bamboo composite in specimen with $6.6 \%$. Meanwhile, there was no difference in tensile strength and modulus elastisity of epoxy sample in room immersion treatment and $50{ }^{\circ} \mathrm{C}$ immersion, the value of that condition is equal $2 \mathrm{MPa}$ for tensile strength and 2 for modulus elastisity.

Tensile properties of bamboo composite can be decrease because of the increases of the temperature of immersion. The tensile properties of bamboo compostite decreases with increasing the temperature of immersion. In addition, tensile properties of bamboo composite and epoxy specimen can be different because in the bamboo composite, there was a filler (woven of bamboo). Bamboo had a hydrophilic group, and causing permanent 
damage in the form of microcracks in the matrix around the swollen fibers. The cracks aggravate water absorption in the composites by promoting capillarity and transport via the microcracks. The absorbed water may damage the fiber matrix interface by forming hydrogen bonding with natural fiber hence reduces the interfacial adhesion. Meanwhile, epoxy specimen not significantly absorb water [14, 23, 26, 27].

\section{Conclustion}

The water absorption of epoxy and bamboo composite affected by temperature of immersion. The water absorpsion of bamboo composite increases with increasing the temperature of immersion. Meanwhile temperature of immersion not affected the epoxy specimen. Tensile stength and modulus elastisity of epoxy and bamboo composite specimen decreases when the sample had immersion treatment. Bamboo composites samples also affected by temperature of immersion. The tensile strength and modulus elastisity decreases with increasing the temperature of immersion.

The authors thank to the Institute of Research and Community Service of Universitas Sebelas Maret for the grant (No.543/UN27.21/PP/2018) provided in conducting this reserch.

\section{References}

1. K.L. Pickering, M.G.A. Efendy, T.M. Le, Compos. Part A Appl. Sci. Manuf. 83: 98-112(2016). https://www.sciencedirect.com/science/article/pii/S1359835X15003115

2. S. Screenivasulu, A. Reddy, Int. J. Eng. Res., 3,3:187-194(2014).

https://www.researchgate.net/publication/269412025_Mechanical_Properties_Evaluati on of Bamboo Fiber Reinforced Composite

3. H. Deng, C.T. Reynolds, N.O. Cabrera, N. Barkoula, B. Alcock, T. Peijs, Compos. Part B, 41,4:268-275(2010). https://www.sciencedirect.com/science/article/pii/S1359836810000363

4. R.P. Venkatesh, K. Ramanathan, V.S. Raman, Fibres. Text. East. Eur., 24,3: 90-94(2016). http://www.fibtex.lodz.pl/article1611.html

5. H.P.S.A. Khalil, I.U.H. Bhat, M. Jawaid, A. Zaidon, D. Hermawan, Y.S. Hadi, Mater. Des., 42:353-368(2012). https://www.sciencedirect.com/science/article/pii/S0261306912003883

6. S.S. Suhaily, H.P.S.A. Khalil, W.O.W. Nadirah, M. Jawaid, Materials Science, 19: 489-517(2013). https://www.intechopen.com/books/materials-science-advancedtopics/bamboo-based-biocomposites-material-design-and-applications

7. H.P.S.A. Khalil, M.S. Alwani, M.N. Islam, S.S. Suhaily, R. Dungani, Y.M.H.M. Jawaid, Biofiber Reinforcements in Composite Materials 2015:488-524(2015). https://www.sciencedirect.com/science/article/pii/B9781782421221500162

8. K.P. Rajan, N.R. Veena, H.J. Maria, R. Rajan, M. Skrifvars, K. Joseph, J. Compos. Mater. 45,12:1325-1329(2011).

https://journals.sagepub.com/doi/abs/10.1177/0021998310381543?journalCode=jcma

9. Michael, E. Surya, Halimatuddahliana, Jurnal Teknik Kimia USU, 2,3:17-21(2013). [in Bahasa Indonesia]. https://docplayer.info/43117785-Jurnal-teknik-kimia-usu-vol-2no-3-2013.html

10. Z.N. Azwa, B.F. Yousif, J. Mater. Des. Appl., 233,6:1065-1079(2017). https://journals.sagepub.com/doi/abs/10.1177/1464420717704221

11. S.K. Hosseinihashemi, F. Arwinfar, A. Najafi, G. Nemli, N. Ayrilmis, J. Int. Meas.

Confed., 86:202-208(2016).

https://www.researchgate.net/publication/294580799_Long- 
term_Water_Absorption_Behavior_of_Thermoplastic_Composites_Produced_with_Th ermally Treated Wood

12. H. Mrad, S. Alix, S. Migneault, A. Koubaa, P. Perré, Meas. J. Int. Meas. Confed.,

115:197-203(2018).

https://www.sciencedirect.com/science/article/pii/S0263224117306358

13. H. Li, K. Song, D. Zhou, Q. Wu, 9,4:6397-6407(2014).

https://ojs.cnr.ncsu.edu/index.php/BioRes/article/view/BioRes_09_4_6397_Li_Durabil ity Treatment Moisture Sorption

14. I. Widiastuti, I. Sbarski, S.H. Masood, Mech. Time-Dependent Mater., 18,2: 387-406(2014). https://link.springer.com/article/10.1007/s11043-014-9233-9

15. I. Widiastuti, Mechanical performance of a PLA-based biodegradable plastic for liquid packaging application. [Thesis] Industrial Research Institute Swinburne (IRIS) Faculty of Engineering and Industrial Science Swinburne University of Technology Melbourne, Australia (2014). https://researchbank.swinburne.edu.au/file/4048d2e44a06-43a2-82e4-4865e168095c/1/Indah\%20Widiastuti\%20Thesis.pdf

16. H.N. Dhakal, Z.Y. Zhang, M.O.W. Richardson, Compos. Sci. Technol., 67,7-8: 1674-1683(2007).

https://www.sciencedirect.com/science/article/pii/S0266353806002363

17. I.K.P. Putra, M.H. Gozali, P.D. Setyawan, Penyerapan air pada epoxy dan poliester tak jenuh dan pengaruhnya pada kekuatan tarik, [Unsaturated epoxy and polyester water absorption and its effect on tensile strength] Proceeding Seminar Nasional Tahunan Teknik Mesin XIV(SNTTM XIV), (Banjarmasin, Indonesia, 2015) XIV: 7-8(2015). [in Bahasa Indonesia]. http://eprints.unlam.ac.id/704/1/Material\%2034.pdf

18. P. Lokantara, N. Putu, G. Suardana, Jurnal Ilmiah Teknik Mesin Cakram, 3,1: 49-56(2009).https://www.e-jurnal.com/2014/08/studi-perlakuan-serat-sertapenyerapan.html

19. I. Widiastuti, M. Solikhun, D.N. Cahyo, Y.R. Pratiwi, H. Juwantono, AIP Conf. Proc. 1977,30046:1-7(2018). https://aip.scitation.org/doi/10.1063/1.5042966

20. P.K. Kushwaha, R. Kumar, Polym. - Plast. Technol. Eng., 49,1:45-52(2010). https://www.tandfonline.com/doi/full/10.1080/03602550903283026

21. Ç. Meriçer, M. Minelli, M.G. Baschetti, T. Lindström, Carbohydr. Polym., 174: 1201-1212(2017). https://www.ncbi.nlm.nih.gov/pubmed/28821046

22. A. Kaboorani, Constr. Build. Mater., 136:164-172(2017). https://www.sciencedirect.com/science/article/abs/pii/S0950061816320414

23. H. Judawisastra, R.D.R. Sitohang, M.S. Rosadi, Mater. Res. Express, 4,9(2017). https://research.utwente.nl/en/publications/water-absorption-and-tensile-strengthdegradation-of-petung-bambo

24. M. Liu, A. Thygesen, J. Summerscales, A.S. Meyer, Ind. Crops Prod., 108: 660-683(2017).

https://www.sciencedirect.com/science/article/pii/S0926669017304880

25. L. Yu, K. Dean, L. Li, Prog. Polym. Sci., 31,6:576-602(2006). https://www.sciencedirect.com/science/article/pii/S0079670006000414

26. H. Jena, A.K. Pradhan, M.K. Pandit, J. Reinf. Plast. Compos., 33,11:1059-1068(2014). https://journals.sagepub.com/doi/abs/10.1177/0731684414523325?journalCode=jrpa

27. H.J. Kim, D.W. Seo, J.K. Lim, T. Fujii, Key Eng. Mater., 306-308:417-422(2006). https://www.scientific.net/KEM.306-308.417 